\title{
Antitumor properties of Salvianolic acid B against triple-negative and hormone receptor-positive breast cancer cells via ceramide- mediated apoptosis
}

\author{
Wei Sha ${ }^{1}$, Yanfei Zhou ${ }^{2}$, Zhi-Qiang Ling ${ }^{3}$, Guiqin Xie ${ }^{1}$, Xiaowu Pang ${ }^{1}$, Paul Wang ${ }^{4,5,6}$ \\ and Xinbin Gu' ${ }^{1,5}$ \\ ${ }^{1}$ Departments of Oral Pathology, College of Dentistry, Howard University, Washington, D.C., USA \\ ${ }^{2}$ TenGen Biomedical Co., Bethesda, Maryland, USA \\ ${ }^{3}$ Zhejiang Cancer Hospital, Zhejiang Cancer Research Institute, Hangzhou, Zhejiang, China \\ ${ }^{4}$ Department of Radiology, College of Medicine, Howard University, Washington, D.C., USA \\ ${ }^{5}$ Cancer Center, Howard University, Washington, D.C., USA \\ ${ }^{6}$ College of Science and Engineering, Fu Jen Catholic University, Taipei, Taiwan \\ Correspondence to: Xinbin Gu, email: xgu@howard.edu \\ Keywords: salvianolic acid B; triple negative breast cancer; apoptosis; ceramides; glucosylceramide synthase \\ Abbreviations: Sal-B: Salvinolic acid B; TNBC: triple-negative breast cancer; ER-a: estrogen receptor a; HER2: human epidermal \\ growth factor receptor-2 \\ Received: August 19, $2018 \quad$ Accepted: October 28, $2018 \quad$ Published: November 20, 2018 \\ Copyright: Sha et al. This is an open-access article distributed under the terms of the Creative Commons Attribution License 3.0 \\ (CC BY 3.0), which permits unrestricted use, distribution, and reproduction in any medium, provided the original author and source \\ are credited.
}

\section{ABSTRACT}

Triple-negative breast cancer (TNBC) is an aggressive subtype of breast cancer with limited treatment options. It is urgent to develop new therapeutics against this disease. Salvinolic acid B (Sal-B) is a leading bioactive component of Salvia miltiorrhiza Bunge, a well-known Chinese medicine for treating various diseases without appreciable adverse effects. To understand the antitumor properties of Sal-B against TNBC, we analyzed its effects on the cell viability, cell cycle and apoptosis of triple-negative MDA-MB-231 cells with the hormone receptor-positive MCF-7 cells as the control. The in vitro analysis showed that Sal-B could significantly reduce the cell viability and suppress the proliferation of both MDA-MB-231 and MCF-7 cells with decreased cyclin B1 expression, but with no noticeable cell cycle phase change. In mouse models, Sal-B markedly inhibited the growth, decreased the PCNA expression, and increased the cell apoptosis of MDA-MB-231 tumor xenografts. To understand the antitumor mechanisms, we analyzed the expression levels of ceramides, and anti-apoptotic (BCl-xL and survivin) and pro-apoptotic (caspase-3 and caspase-8) proteins. We found that Sal-B enhanced the ceramide accumulation and inhibited the anti-apoptotic protein expression. Interestingly, the ceramide accumulation was accompanied by decreased expression of glucosylceramide and GM3 synthases, two key enzymes regulating ceramide metabolism. These findings indicate that Sal-B exerts its antitumor effects at least partially by inducing the ceramide accumulation and ceramide-mediated apoptosis via inhibiting the expression of glucosylceramide and GM3 synthases, which was independent of estrogen receptor $\mathbf{a}$. Sal-B appears to be a promising therapeutic agent against TNBC.

\section{INTRODUCTION}

Breast cancer is the most common cancer in women and the second highest lethal form of cancer in the United States [1]. Studies have shown that the incidence of breast cancer has been gradually decreasing in the last two decades, however women in the United States still have a one in eight chance of developing breast cancer in their lifetime [2]. Critically, about one third of breast cancer is triple-negative (TNBC), presenting the lack of expression 
of estrogen receptor $\alpha$ (ER- $\alpha)$, progesterone receptor, and human epidermal growth factor receptor-2 (HER2) [3]. Due to the poor response to anti-hormonal treatment and chemotherapeutics, TNBC is considered an aggressive form of breast cancer [3]. The commonly used therapeutic agents for breast cancer including doxorubicin have little success in treating patients with TNBC [4]. In addition, the cardiotoxicity risk of doxorubicin also limits its clinical applications $[5,6]$.

The sphingolipids, such as ceramides, play an important biological role in the regulation of proliferation, differentiation, and apoptosis of cancer cells [7-9]. Intracellular ceramide accumulation has been shown to enhance the apoptosis of cancer cells [10-12]. Development of drug resistance of cancer cells is also associated with an increase in ceramide glycosylation [13-15]. Glucosylceramide synthase (GCS) is a key enzyme in the metabolism of ceramide glycosylation, which converts ceramide to glucosylceramide. Early inhibition of GCS has potential to prevent the drug resistance [13]. In addition, the TNF- $\alpha$-induced apoptosis pathway is also involved in the process of increasing intracellular ceramides [16].

Salvianolic acid B (Sal-B) is a natural compound extracted from Salvia Miltorrhiza Bunge, a well-known Chinese herbal medicine for preventing and treating vascular diseases. Sal-B is also a quality control ingredient and an active marker for S. Miltorrhiza Bunge products by the National Pharmacopoeia Council of China [17-19]. In the previous studies, we have found that Sal-B has a suppressing effect against head and neck squamous carcinoma cells [19]. This anticancer effects of Sal-B have been shown to involve in various mechanisms [20-26]. A recent study has revealed that the effect of Sal-B on human glioblastoma U87 cells is through p38 activationmediated reactive oxygen species generation [22]. In the present study, we analyzed the antitumor properties of Sal-B against triple-negative MDA-MB-231 cells using the hormone receptor-positive MCF-7 cells as the control. The results showed that Sal-B had a high potency against TNBC, which was mediated by inhibiting the tumor cell growth and enhancing the ceramide-mediated apoptosis through GCS-catalyzed ceramide glycosylation.

\section{RESULTS}

\section{Sal-B inhibited the growth of both triple- negative and hormone receptor-positive breast cancer cells in vitro}

We used the TNBC MDA-MB-231 cell line and hormone receptor-positive MCF-7 cell line to test the effectiveness of Sal-B and doxorubicin on the cancer cell viability (Figure 1A and 1B). Both cell lines have been stably transfected and expressed the firefly luciferase gene. The bioluminescent signal intensity reflects the cell metabolic activity, being highly correlated with the cell viability. Therefore we evaluated the cell viability using the sensitive bioluminescent optical imaging. The cells were treated with Sal-B $(50,100,150$, and $200 \mu \mathrm{M})$ and doxorubicin $(0.1,0.2,0.5$, and $1 \mu \mathrm{M})$, respectively, for 24 hours. We observed a similar inhibitory effect of Sal-B on the cell viability of both MDA-MB-231 and MCF-7 cells in a dose-dependent manner. Compared with untreated cells, MDA-MB-231 and MCF-7 cells decreased their cell viabilities to $69 \%$ and $65 \%$, respectively, when treated with Sal-B at $100 \mu \mathrm{M}$ for 24 hours (Figure 1A). The half maximal inhibitory concentrations $\left(\mathrm{IC}_{50}\right)$ were $125 \mu \mathrm{M}$ for MDA-MB-231 cells and $120 \mu \mathrm{M}$ for MCF-7 cells. There was no significant difference for the inhibitory effect of Sal-B between the two cell lines. Differentially, doxorubicin was more effective on the inhibition of MCF-7 than MDA-MB-231 cell growth (Figure 1B). At $0.5 \mu \mathrm{M}$ concentration, doxorubicin reduced the viability of MCF-7 cells by approximately $67 \%$, whereas there was only $25 \%$ reduction for the MDA-MB-231 cells $(P<0.05)$. No further reduction of the cell viability was observed in both cell lines treated with $1 \mu \mathrm{M}$ doxorubicin.

\section{Sal-B suppressed the colony formation of breast cancer cells}

The effect of Sal-B on the cancer cells was further tested with colony formation assay (Figure 1C). The colony contained more than 50 cells was considered to represent a viable clonogenic cell after 10 days following exposure for 24 hours to Sal-B at varied concentrations $(1,10,20,50$, and $100 \mu \mathrm{M})$. As shown in Figure 1C, the colony formation capability of the cells treated at the concentration of $1 \mu \mathrm{M}$ was approximately $69 \%$ of that of the control cells, and a complete inhibition of the cell colony formation capability was observed at $100 \mu \mathrm{M}$.

To understand the effects of Sal-B on the cell cycle of cancer cells, we analyzed the cell cycle profile using flow cytometry. There were no significant changes in the cell cycle phases for either MDA-MB-231 or MCF-7 cells after exposure for 24 hours to Sal-B at concentrations of $50 \mu \mathrm{M}$ (Figure 2A and 2C) and $100 \mu \mathrm{M}$ (Figure 2B and $2 \mathrm{C})$. When checking the expression of two cell cyclerelated proteins, cyclin $\mathrm{A}$ and cyclin $\mathrm{B} 1$, we observed that Sal-B was able to down-regulate the cyclin B1 expression in both MDA-MB-231 and MCF-7 cells, but had no significant effect on cyclin A protein expression (Figure 2D). Treatment with $1 \mu \mathrm{M}$ doxorubicin resulted in a significant reduction of both cyclin A and cyclin B1 expression in both cell lines.

\section{Inhibitory effect of Sal-B on the growth of TNBC MDA-MB-231 tumor xenografts}

The above findings showed that Sal-B could inhibit the proliferation of MDA-MB-231 cells in vitro. We thus 
tested the effects of Sal-B on the growth of MDA-MB-231 tumor xenografts in animals. The treatment was initiated 10 days after MDA-MB-231 cells were transplanted into the nude mice, and at that time, the tumor mass in each mouse was about $5 \mathrm{~mm}$ in diameter. Our previous studies have shown that treatment with Sal-B at $80 \mathrm{mg} / \mathrm{kg}$ three times per week leads to no obvious side effects, but a higher dosage has resulted in the weight loss in some mice. Also based on publications regarding doxorubicin, the agents were administered by intraperitoneal injection with

A MCF-7
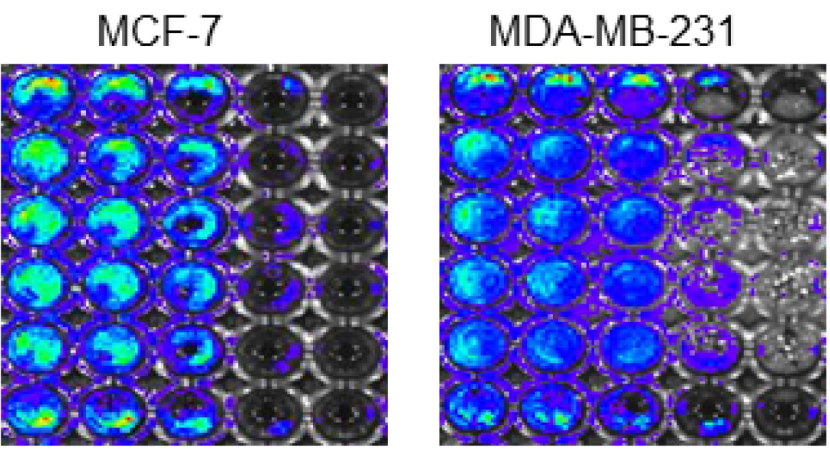

$\begin{array}{lllll}0 & 50 & 100 & 150 & 200\end{array}$

$\begin{array}{llll}0 & 50 & 100 & 150200\end{array}$ Sal-B $(\mu M)$

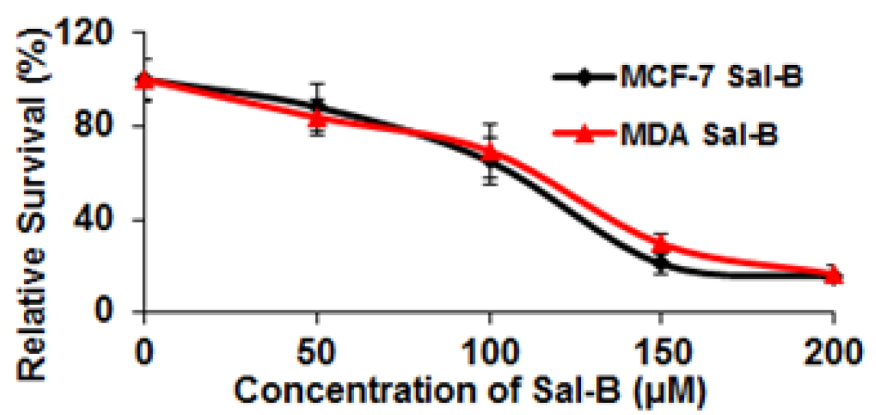

C

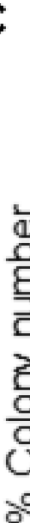

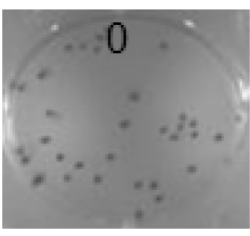
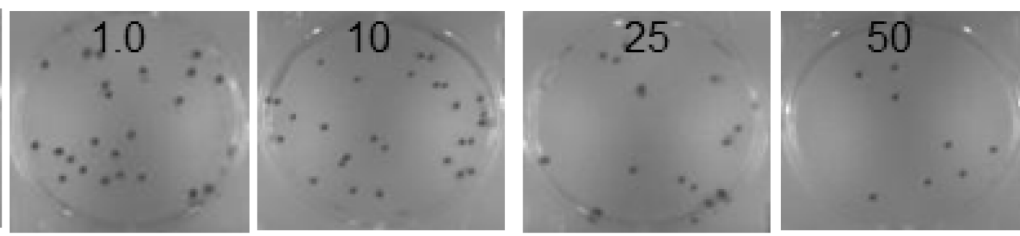

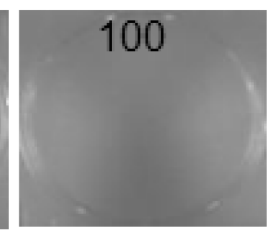

B
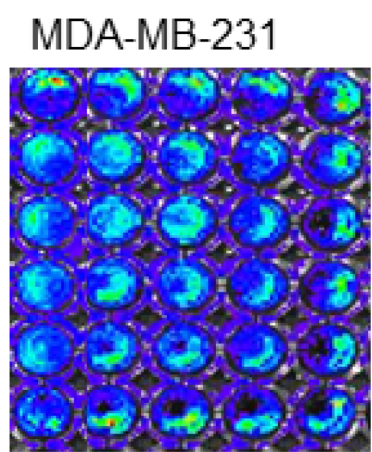

$\begin{array}{llll}0 & 0.1 & 0.2 & 0.51\end{array}$

Doxorubicin $(\mu \mathrm{M})$

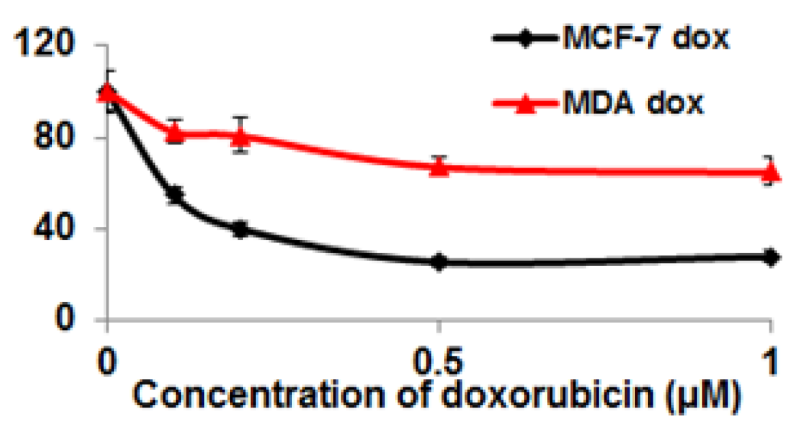

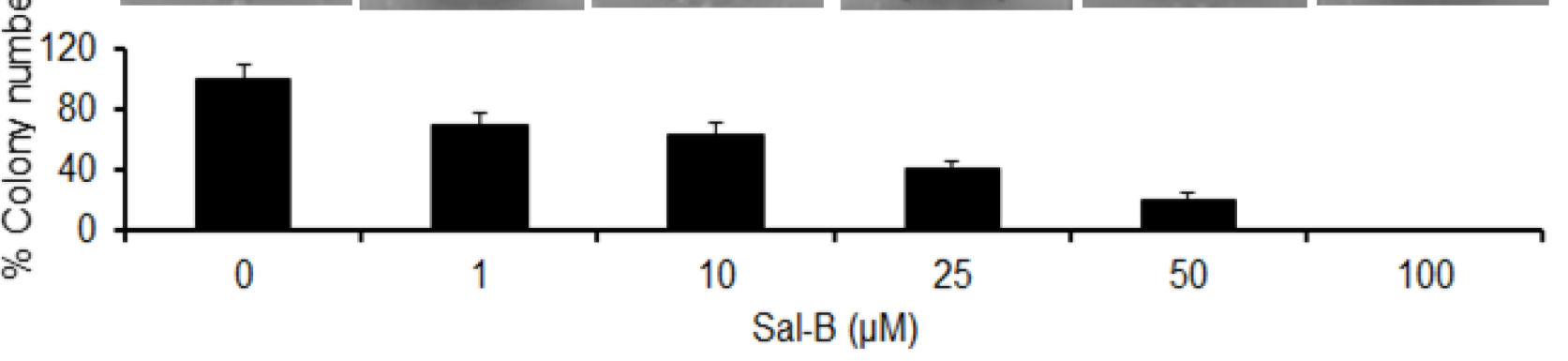

Figure 1: Inhibitory effects of Sal-B on the cell viability and colony formation of both triple-negative MDA-MB-231 and hormone-receptor positive MCF-7 breast cancer cells. The cell viability was analyzed by luciferase-based bioluminescent imaging after exposure to Sal-B $(50 \mu \mathrm{M}, 100 \mu \mathrm{M}, 150 \mu \mathrm{M}$ and $200 \mu \mathrm{M})(\mathbf{A})$ and doxorubicin $(0.1 \mu \mathrm{M}, 0.2 \mu \mathrm{M}, 0.5 \mu \mathrm{M}$ and $1 \mu \mathrm{M})(\mathbf{B})$ for $24 \mathrm{~h}$, respectively. The colony formation of MDA-MB-231 cells was determined with colony formation assay after exposure to various doses of Sal-B $(1 \mu \mathrm{M}, 10 \mu \mathrm{M}, 25 \mu \mathrm{M}, 50 \mu \mathrm{M}$ and $100 \mu \mathrm{M})$ for $24 \mathrm{~h}$ and colonies were allowed to grow for 10 days $(\mathbf{C})$. A colony containing more than 50 cells was considered to represent a viable clonogenic cell. The results represent the mean \pm SD. There were significant differences for the cell viability and colony formation capability between untreated and Sal-B treated cells $(P<0.05)$. No significant difference was observed for the effect of Sal-B on the cell viability between MDA-MB-231 and MCF-7 cells $(P>0.05)$, different from that of doxorubicin $(P<0.05)$. 
Sal-B at $80 \mathrm{mg} / \mathrm{kg}$ three times per week, and doxorubicin at $4 \mathrm{mg} / \mathrm{kg}$ every four weeks for a total of 37 days. As shown in Figure 3A, the average tumor weights of Sal-B treated group $(0.26 \pm 0.06 \mathrm{~g})$ and doxorubicin treated group $(0.34 \pm 0.09 \mathrm{~g})$ were both significantly smaller than that of untreated control group $(0.81 \pm 0.12 \mathrm{~g})$ (both
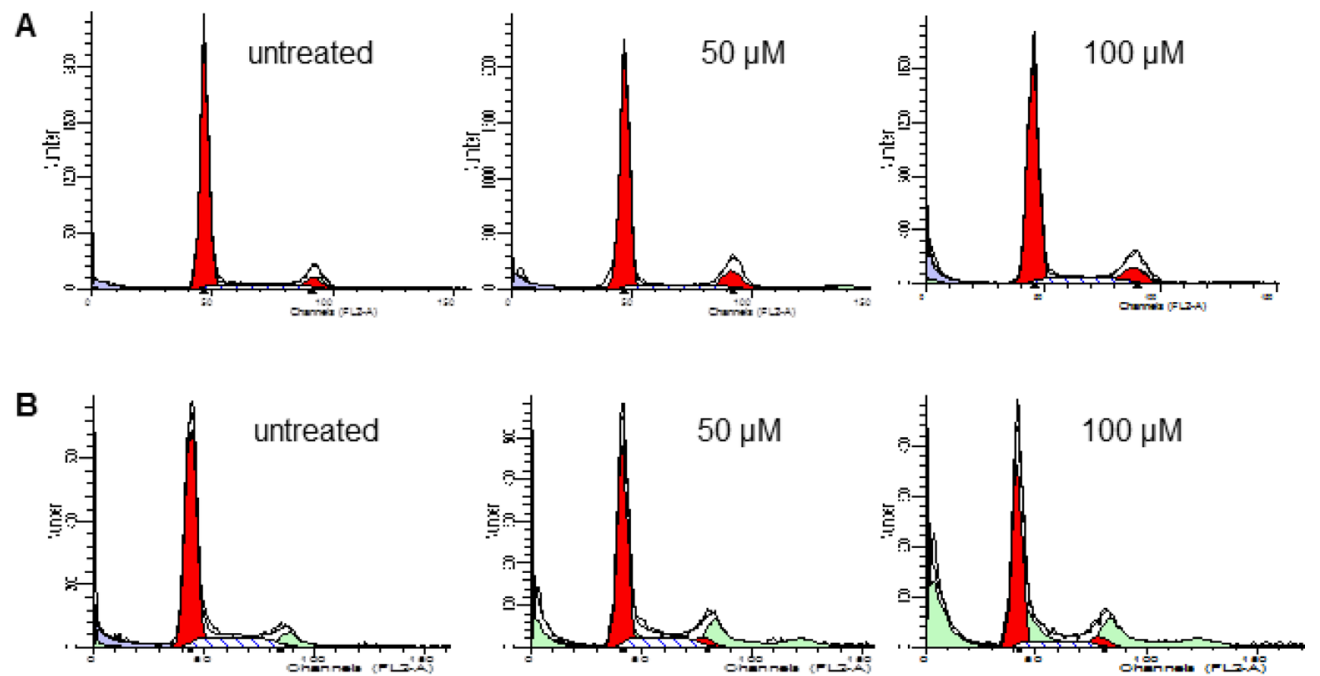

\section{C.}
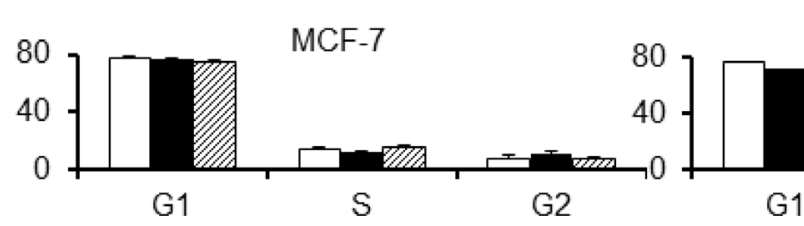

$\square 0$
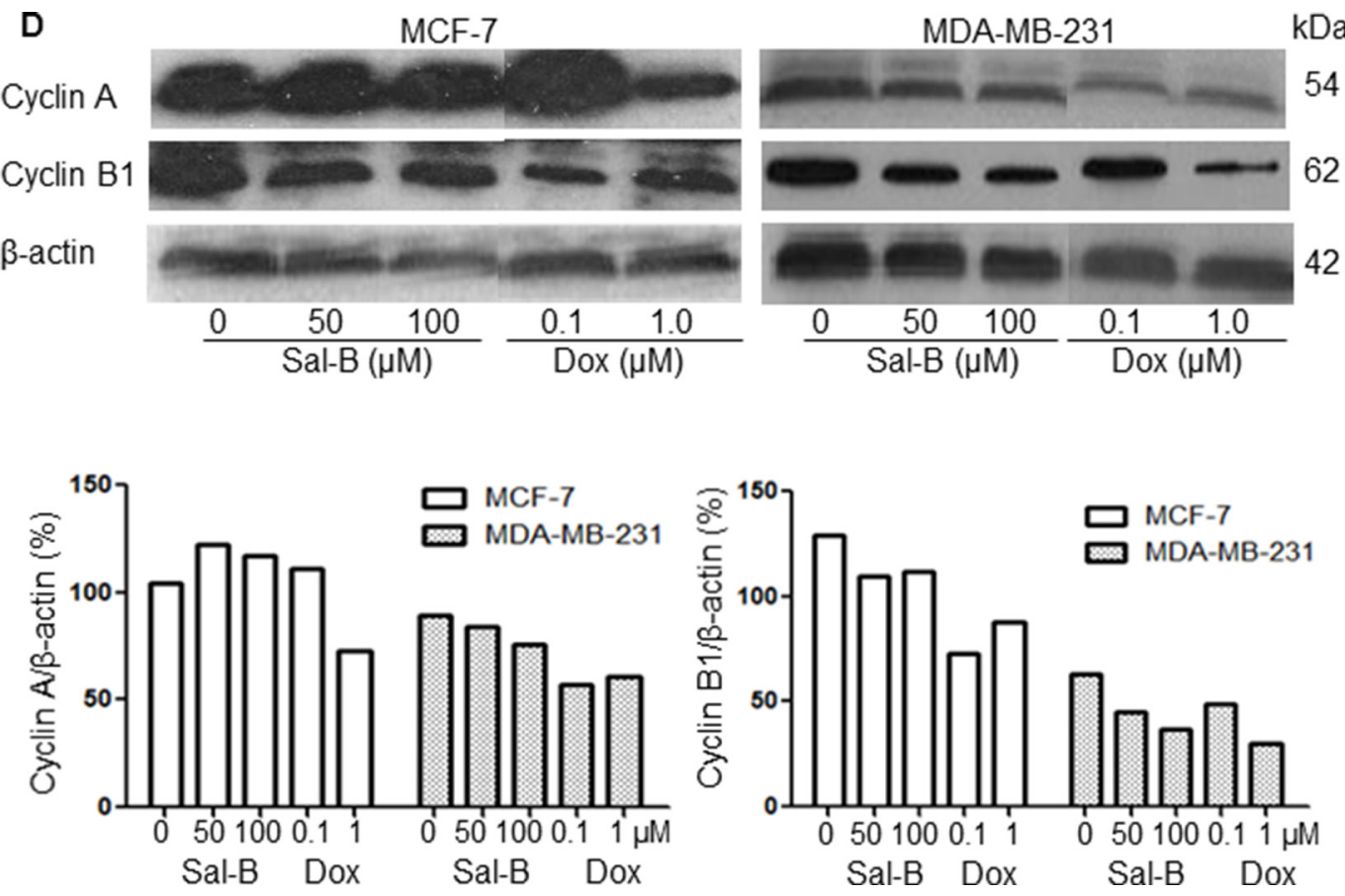

Figure 2: Effects of Sal-B on cell cycle and cell cycle related protein expression in MCF-7 and MDA-MB-231 cells. (A, B) show the DNA content profiles of MCF-7 and MDA-MB-231 cells, respectively, by flow cytometry. The percentages of cells in the different phases of cell cycle are summarized as mean $\pm \mathrm{SD}(\mathbf{C})$. The upper panel of (D) shows the Western blot analysis for the expression of cell cycle related protein cyclin A and cyclin B1. The expression of cyclin A and cyclin B1 was normalized by the expression of the internal control $\beta$-actin (lower panel). The cells were treated with $50 \mu \mathrm{M}$ and $100 \mu \mathrm{M}$ Sal-B, respectively, for $24 \mathrm{~h}$. Doxorubicin $(0.1 \mu \mathrm{M}$ and $1 \mu \mathrm{M}$ ) was used as a control. No significant change was observed in the cell cycle phases of either MDA-MB-231 or MCF-7 cells after Sal-B treatment. For the cyclin A and cyclin B1 expression, down-regulation of cyclin B1 but not cyclin A expression was found in both Sal-B treated MDA-MB-231 and MCF-7 cells. Treatment with $1 \mu \mathrm{M}$ doxorubicin resulted in reduction of both cyclin A and cyclin B1 expression in both cell lines. 
$P<0.05)$. During the experimental period, body weights of mice were measured every week and there were no significant differences between untreated mice and treated mice (data not shown). In parallel with the decreased tumor growth, a lower expression level of proliferating cell nuclear antigen (PCNA) was observed in Sal-B treated and doxorubicin treated tumor xenografts than in untreated MDA-MB-231 tumor xenografts (Figure 3B).

\section{Effects of Sal-B on the expression of apoptosis- related proteins and apoptosis in MDA-MB-231 and MCF-7 cancer cells}

The effect of Sal-B on the apoptosis of MDAMB-231 and MCF-7 cells was analyzed in vitro and in tumor xenografts with different methods. We first investigated the levels of apoptosis-related proteins
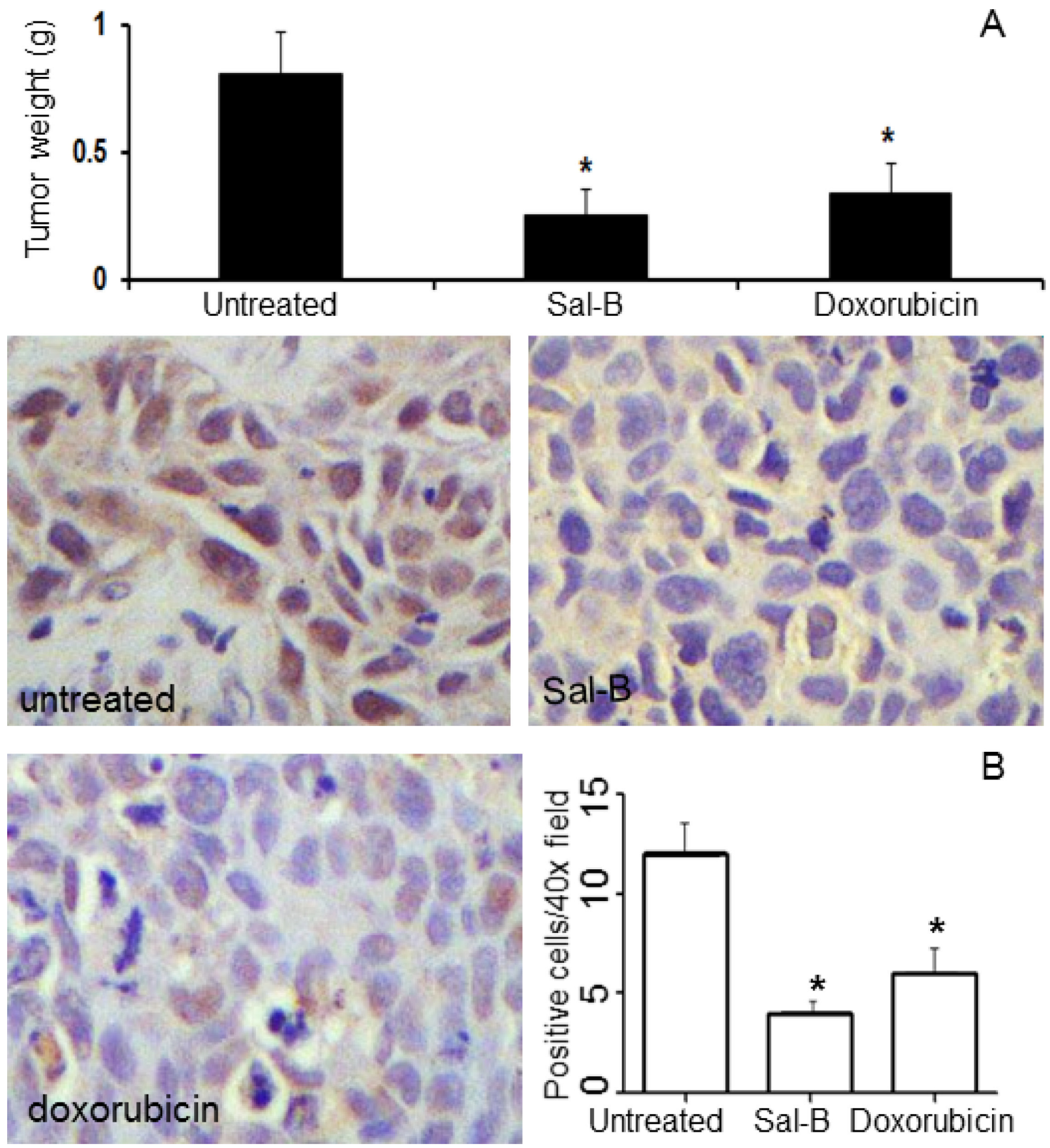

Figure 3: Inhibitory effects of Sal-B on the growth of triple-negative MDA-MB-231 tumor xenografts in nude mice. The mice were treated with either Sal-B $(80 \mathrm{mg} / \mathrm{kg}$ three times per week) or doxorubicin $(4 \mathrm{mg} / \mathrm{kg}$ every 4 weeks) and all mice were sacrificed on day 37. (A) shows the tumor weights on day 37. The PCNA levels were higher in untreated tumors than in Sal-B treated and doxorubicin treated tumors, as determined by immunohistochemical analysis (B). The results represent the mean $\pm \mathrm{SD}^{\text {and }}{ }^{*} P<0.05$ means significant difference with respect to control mice. 
in vitro, including two anti-apoptotic (Bcl-xL and survivin) and two pro-apoptotic (caspase-3 and caspase-8) proteins using Western blot analysis (Figure 4A). Sal-B treatment downregulated both Bcl-xL and survivin protein expression, but not the protein levels of caspase- 3 and caspase- 8 in the MDA-MB-231 and MCF-7 cells. Similar results to Sal-B were observed for doxorubicin. The expression of Bcl-xL and survivin in MDA-MB-231 tumor xenografts was further analyzed by immunohistochemistry. The expression of Bcl-xL decreased significantly in the Sal-B treated tumors $(1.3$ $\pm 0.4)$ than in untreated tumors $(11.8 \pm 3.0)(P<0.05)$ (Figure 4B). Survivin level showed similar changes, decreasing in Sal-B and doxorubicin treated groups compared to that in untreated group (Figure 4C). The immunohistochemical results were consistent with those from Western blotting.

We then investigated the apoptotic cells in the tumors using TUNEL assay. As the results, the highest number of apoptotic cells was found in the Sal-B treated xenografts $(12.2 \pm 3.2)$, followed by doxorubicin treated xenografts $(9.0 \pm 2.1)$, significantly different from that in the untreated tumors $(3.1 \pm 1.8)$ (both $P<0.05)$ (Figure 4D).

\section{Sal-B increased ceramide accumulation and inhibited GCS and GM3 synthase expression}

Ceramide level was analyzed with flow cytometry through comparison between Sal-B treated and untreated MDA-MB-231 cells. We observed that $50 \mu \mathrm{M}$ of Sal-B was sufficient to enhance the ceramide level (Figure 5A). In line with this result, immunohistochemical analysis revealed that ceramide level significantly increased in both Sal-B treated $(9.6 \pm 2.4)$ and doxorubicin treated $(6.2 \pm 1.3) \mathrm{MDA}-\mathrm{MB}-231$ tumor xenografts, compared to that in untreated control $(2.3 \pm 0.7)$ (both $P<0.05)$ (Figure $5 \mathrm{~B}$ and $5 \mathrm{C}$ ). To understand the mechanism underlying increased ceramide accumulation, we measured the expression levels of GCS and GM3 synthases using Western blot analysis. As shown in Figure 5D and 5E, a low dose $(50 \mu \mathrm{M})$ of Sal-B was sufficient to inhibit GCS protein level in both MCF-7 and MDA-MB-231 cells. There was no further inhibitory effect on GCS expression when treated with a higher dose $(100 \mu \mathrm{M})$, compared with the low dose $(50 \mu \mathrm{M})$. The expression of GM3 synthase was also significantly diminished in the Sal-B treated MDA-MB-231 cells at both $50 \mu \mathrm{M}$ and $100 \mu \mathrm{M}$, and in the MCF-7 cells at $100 \mu \mathrm{M}$ (Figure 5D and 5F).

\section{No effects of Sal-B on the ER- $\alpha$ and p-ERK expression in breast cancer cells}

To understand whether Sal-B regulated the expression of ER- $\alpha$, we investigated the ER- $\alpha$ expression in MCF-7 cells. The results showed that ER- $\alpha$ protein level was decreased by exposure to doxorubicin at the high dose $(1 \mu \mathrm{M})$, but not to Sal-B (Figure 6A). Considering that phospho-p44/42 extracellular signal-regulated kinases (p-ERK) is a key enzyme in the MAPK signal pathway, we checked the expression of p-ERK and found that it was down-regulated by Sal-B in both MCF-7 and MDAMB-231 cells (Figure 6B).

\section{DISCUSSION}

TNBC is an aggressive subtype of breast cancer, which tends to grow and spread more quickly than other subtypes [27-30]. Available endocrine and HER2-directed therapies are ineffective against TNBC. Chemotherapy has been shown to be the most effective treatment for TNBC with the anthracycline drug, doxorubicin, being considered to be one of the most effective chemotherapeutic agents [31-35]. However, the clinical efficacy of doxorubicin is limited by the drug resistance development and severe side effects [36-39]. There is an urgent need to develop new therapeutics against TNBC.

Our previous studies have indicated that Sal-B is a unique natural anticancer agent that effectively inhibits the growth of head and neck cancer without significant side effects $[19,24]$. In this study, we evaluated the antitumor property of Sal-B against TNBC MDA-MB-231 cells and compared it with that against hormone receptor-positive MCF-7 cells. We first found that Sal-B was able to reduce the cell viability of both MDA-MB-231 and MCF-7 cells in vitro; showing an $\mathrm{IC}_{50}$ of $125 \mu \mathrm{M}$ for MDA-MB-231 cells and $120 \mu \mathrm{M}$ for $\mathrm{MCF}-7$ cells. No significant difference was observed for this effect of Sal-B between the two cell lines. Differently, the effect of doxorubicin $(1 \mu \mathrm{M})$ on the cell viability was approximately two-fold higher for MCF-7 cells than for MDA-MB-231 cells. The inhibitory effect of Sal-B was further confirmed by colony formation assay. These results indicate that Sal-B has an inhibitory effect on TNBC cell growth in vitro.

We then tested the effect of Sal-B on the cell cycle progression of TNBC cells. We did not found a significant change in each phase of the cell cycle for both MDA-MB-231 and MCF-7 cells after exposure for 24 hours to Sal-B at concentration of either $50 \mu \mathrm{M}$ or $100 \mu \mathrm{M}$, but Sal-B down-regulated the expression of cyclin B1. The results may be explained by that the cell cycle progression is controlled by a large set of molecules, although cyclin B1 is a key component in the control of cell cycle progression from G2 to M phase. Differently, doxorubicin effectively decreased the expression of both cyclin A and cyclin B1 in both cell lines. The expression of cell cycle related proteins has been found to be higher in doxorubicin-resistant breast cancer cells and doxorubicin could induce prostate cancer apoptosis by inhibiting cyclin B1 expression [39, 40].

The results obtained from in vitro studies were consistent with those from the animal model of TNBC. 
In the animals, Sal-B significantly inhibited the growth of MDA-MB-231 tumor xenografts. To understand the mechanisms underlying the antitumor effect of Sal-B, we investigated whether Sal-B could induce apoptosis of MDA-MB-231 tumor xenografts. As the results, a higher number of apoptotic cells was found in the Sal-B
A

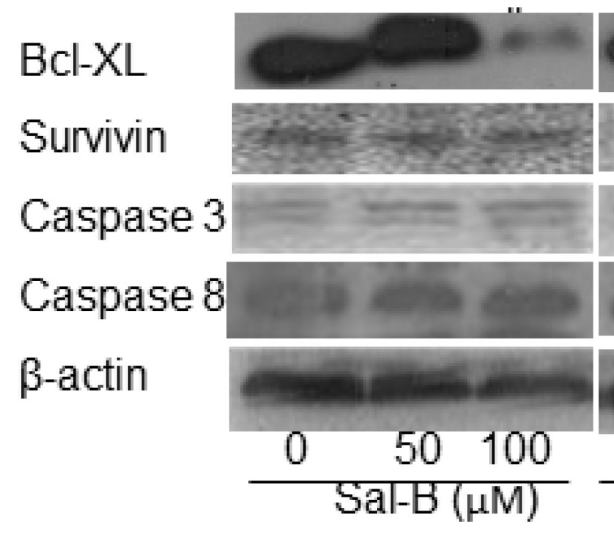

B
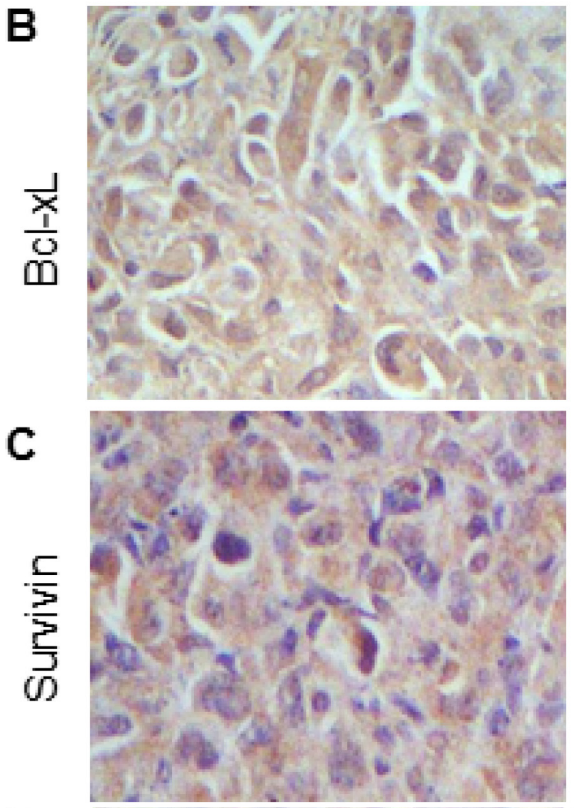

D

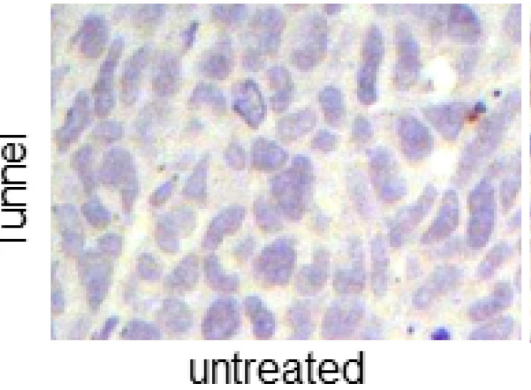

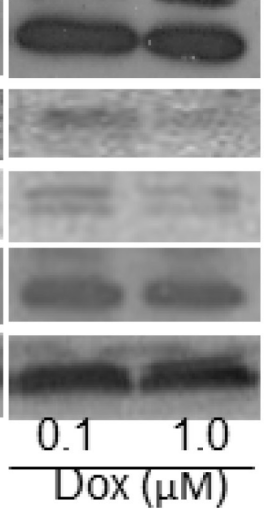

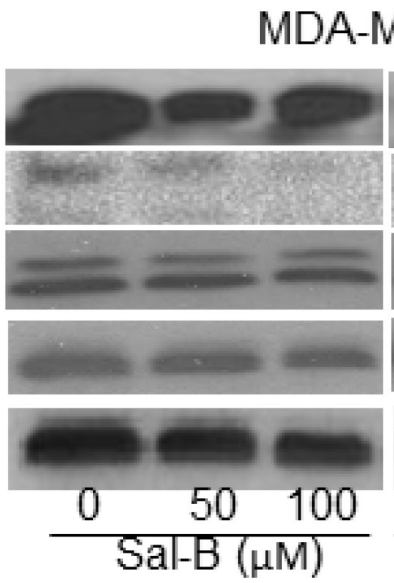

MDA-MB-231

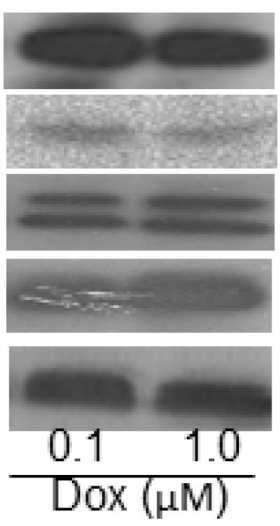

$\mathrm{kDa}$

28

16

32

12

43

42
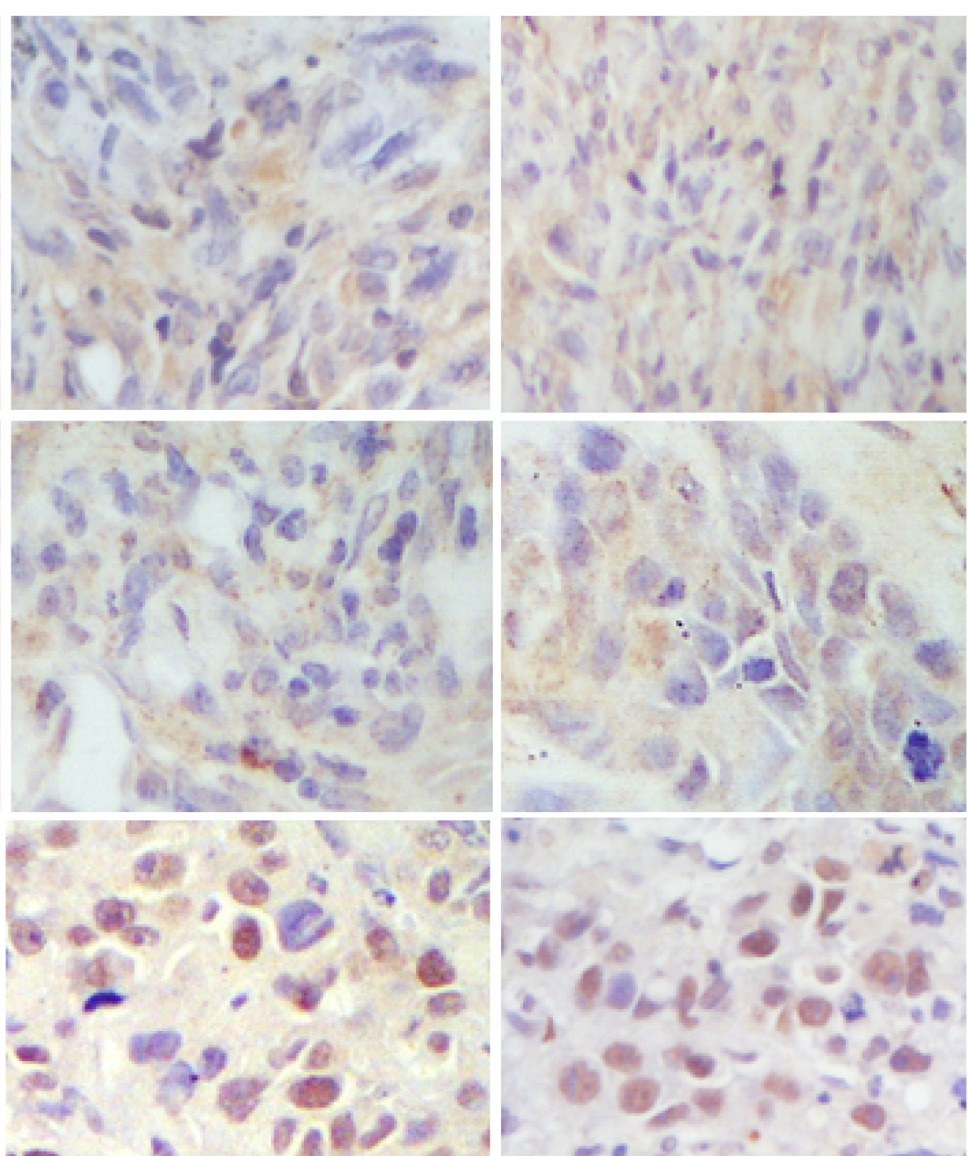

Sal-B

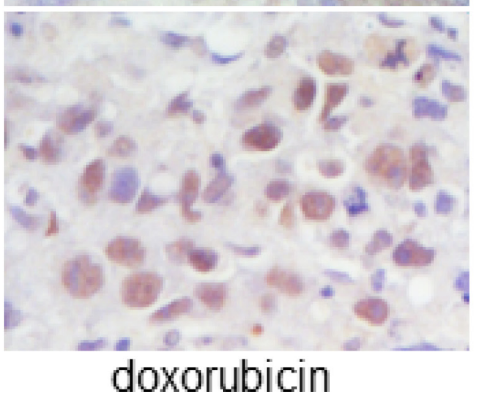

Figure 4: Effects of Sal-B on the apoptosis in both MCF-7 and MDA-MB-231 cancer cells and tumor xenografts. Western blot analysis was used to determine the expression of apoptosis-related proteins Bcl-xL, survivin, caspase-3 and caspase-8 (A). $\beta$-actin was used as an internal control for Western blotting. The cells were treated with Sal-B (50 $\mu \mathrm{M}$ and $100 \mu \mathrm{M})$ and doxorubicin $(0.1$ $\mu \mathrm{M}$ and $1 \mu \mathrm{M}$ ), respectively, for $24 \mathrm{~h}$. Both Sal-B and doxorubicin downregulated both Bcl-xL and survivin protein expression, but not the protein levels of caspase-3 and caspase- 8 in the MDA-MB-231 and MCF-7 cell lines. Immunohistochemical analysis was used to detect the expressions of Bcl-xL (B) and survivin (C) in MDA-MB-231 tumor xenografts, showing decreased expression of Bcl-xL and survivin in the Sal-B and doxorubicin treated tumors than in the untreated tumors $(P<0.05)$. Apoptotic cells in MDA-MB-231 tumor xenografts were analyzed by a TUNEL assay, showing an increased apoptotic cells in the Sal-B and doxorubicin treated xenografts than in the untreated tumors $(P<0.05)(\mathbf{D})$. 
treated tumors than the control tumors, and the increased apoptosis was accompanied by ceramide accumulation in cancer cells in vitro as well as in tumor xenografts. These results suggest that ceramide-mediated cell apoptosis may play a critical role in the effect of Sal-B against TNBC. To further understand the ceramide metabolism, we analyzed the expression of GCS and GM3 synthases. GCS is a key enzyme to convert ceramide to glucosylceramide, catalyzing the first reaction of ceramide glycosylation in sphingolipid metabolism, while GM3 synthase catalyzes the initial step in the biosynthesis of most complex gangliosides from lactosylceramide. Both synthases
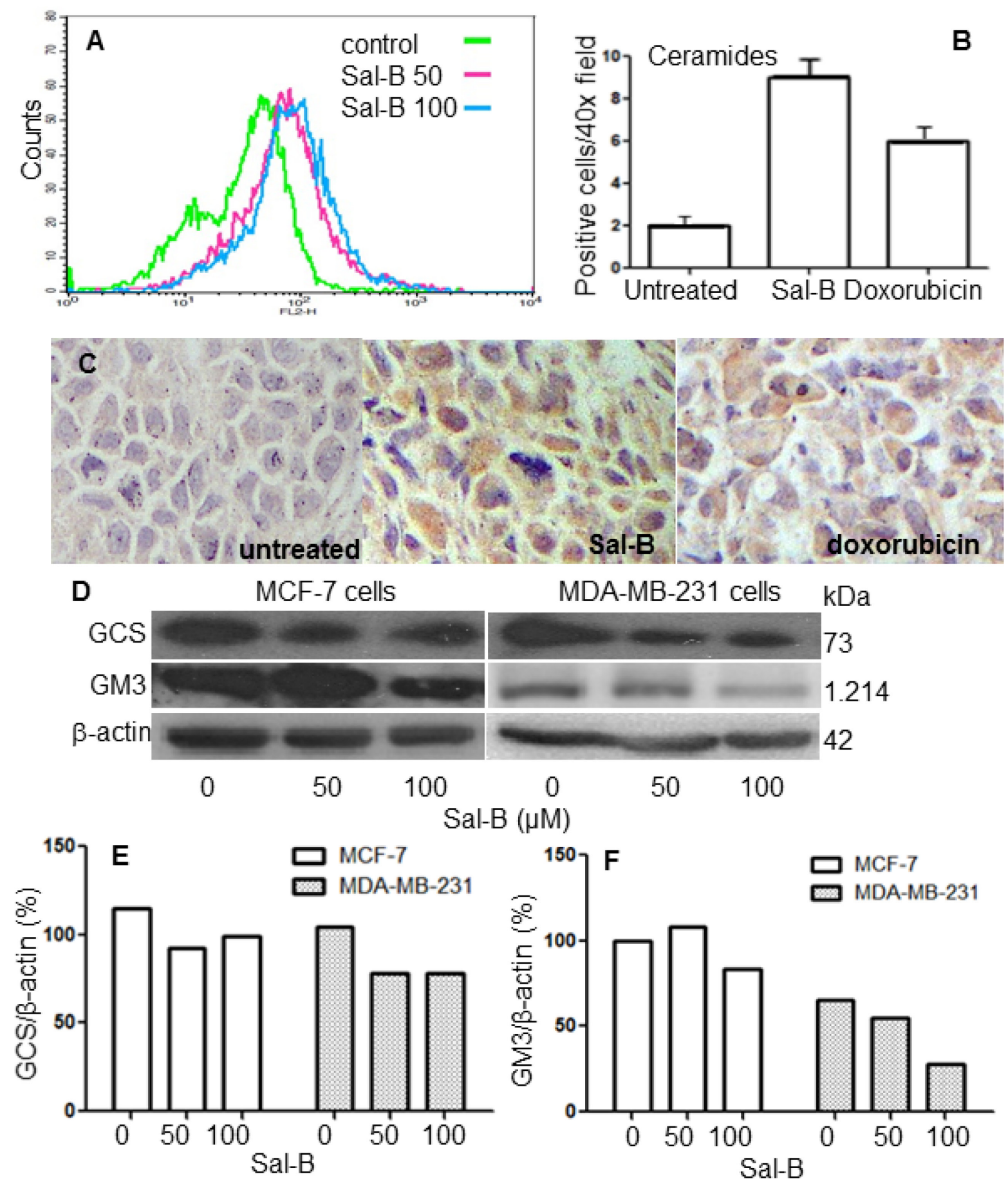

$0 \quad 50 \quad 100$

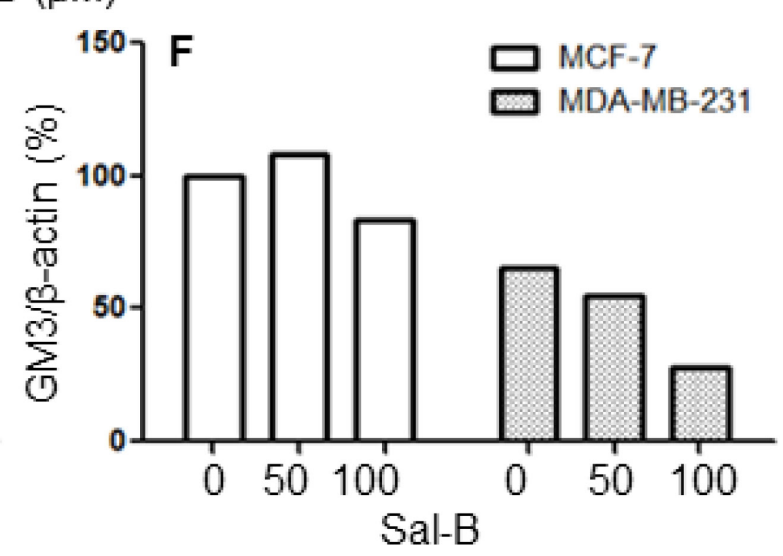

Figure 5: Sal-B enhances ceramide accumulation and decreases the expression of GCS and GM3 enzymes. MDAMB-231 cells were treated with $50 \mu \mathrm{M}$ and $100 \mu \mathrm{M}$ of Sal-B, respectively, for $24 \mathrm{~h}$ and ceramide levels were then analyzed by flow cytometry (A). Immunohistochemistry was used to evaluate the expression of ceramides in MDA-MB-231 tumor xenografts (C) and the ceramide positive cells were counted (B). The expression of GCS and GM3 synthase in MDA-MB-231 and MCF-7 cells treated by various concentrations of Sal-B was determined with Western blotting (D). The amount of protein expression was normalized by the expression of the internal control $\beta$-actin $(\mathbf{E}$ and $\mathbf{F})$. 
closely regulate the ceramide metabolism. We found that Sal-B effectively down-regulated GCS and GM3 enzyme expression in cancer cells. Suppression of GCS and GM3 enzymes by Sal-B may lead to the accumulation of ceramides in cancer cells. Doxorubicin has also been shown to induce ceramide accumulation in cancer cells by other studies [41-43]. Both Sal-B and doxorubicin may induce TNBC cell apoptosis through the ceramidemediated pathway.

Doxorubicin is known to induce apoptosis of breast cancer cells by regulating the expression of apoptosis-related proteins and some members of caspase-family enzymes [44]. Keeping these in mind, we studied whether Sal-B could regulate the expression of anti-apoptotic proteins (Bcl-xL and survivin) and caspase enzymes (caspase-3 and caspase-8), similar to doxorubicin. Our results showed that neither Sal-B nor doxorubicin could significantly change the caspase- 3 and caspase- 8 in TNBC cells, suggesting the less involvement of death-receptor (extrinsic) pathway. Interestingly, both Sal-B and doxorubicin inhibited Bcl-xL and survivin expression, indicating the involvement of the mitochondrial (intrinsic) pathway. Taken these together, we propose that the antitumor effect of Sal-B against TNBC is taken at least partially through a ceramide-centered mechanism (Figure 7).

The MAPK/ERK pathway is a chain of proteins in the cells, which communicates a signal from a receptor on the surface of cells to the DNA in the nucleus of the cells, critical for establishing solid tumor growth, especially for breast cancer. P-ERK is a critical member in MAPK signal pathway and also a marker of the activation of MAPK signal pathway in up-regulating cell proliferation.
We observed that Sal-B significantly decreased the p-ERK expression in both cell lines, suggesting that Sal-B might inhibit cell proliferation of TNBC cells by regulating MAPK signal pathway. Ceramides may interact with the MAPK pathway through inhibiting the p-ERK expression, but the mechanism is still not clear. A recent study has shown that the three receptor tyrosine kinases c-KIT, VEGFR2 and PDGFR $\alpha$ are increased in TNBC [44].

In summary, our studies demonstrated that Sal-B could effectively inhibit the growth of both culture MDAMB-231 cells and tumor xenografts through a ceramidemediated pathway. Sal-B enhanced the cell apoptosis and decreased cell proliferation of TNBC by regulating the ceramide glycosylation enzymes. Given the fact that the currently available chemotherapeutic agents including doxorubicin are usually associated with severe side effects and less effective against TNBC, Sal-B provides promise as an effective anticancer agent with low toxicity, although studies are necessary to further elucidate the antitumor effects on other types of cancer and the underlying mechanisms. It is also interesting to investigate whether combination of Sal-B and other chemotherapeutic agents will provide an effective therapeutic strategy to improve the clinical outcome.

\section{MATERIALS AND METHODS}

\section{Chemical reagents and antibodies}

Sal-B was isolated and purified from Salvia miltiorrhiza Bunge as described previously [19]. Briefly, Sal-B was first extracted from Salvia miltiorrhiza Bunge
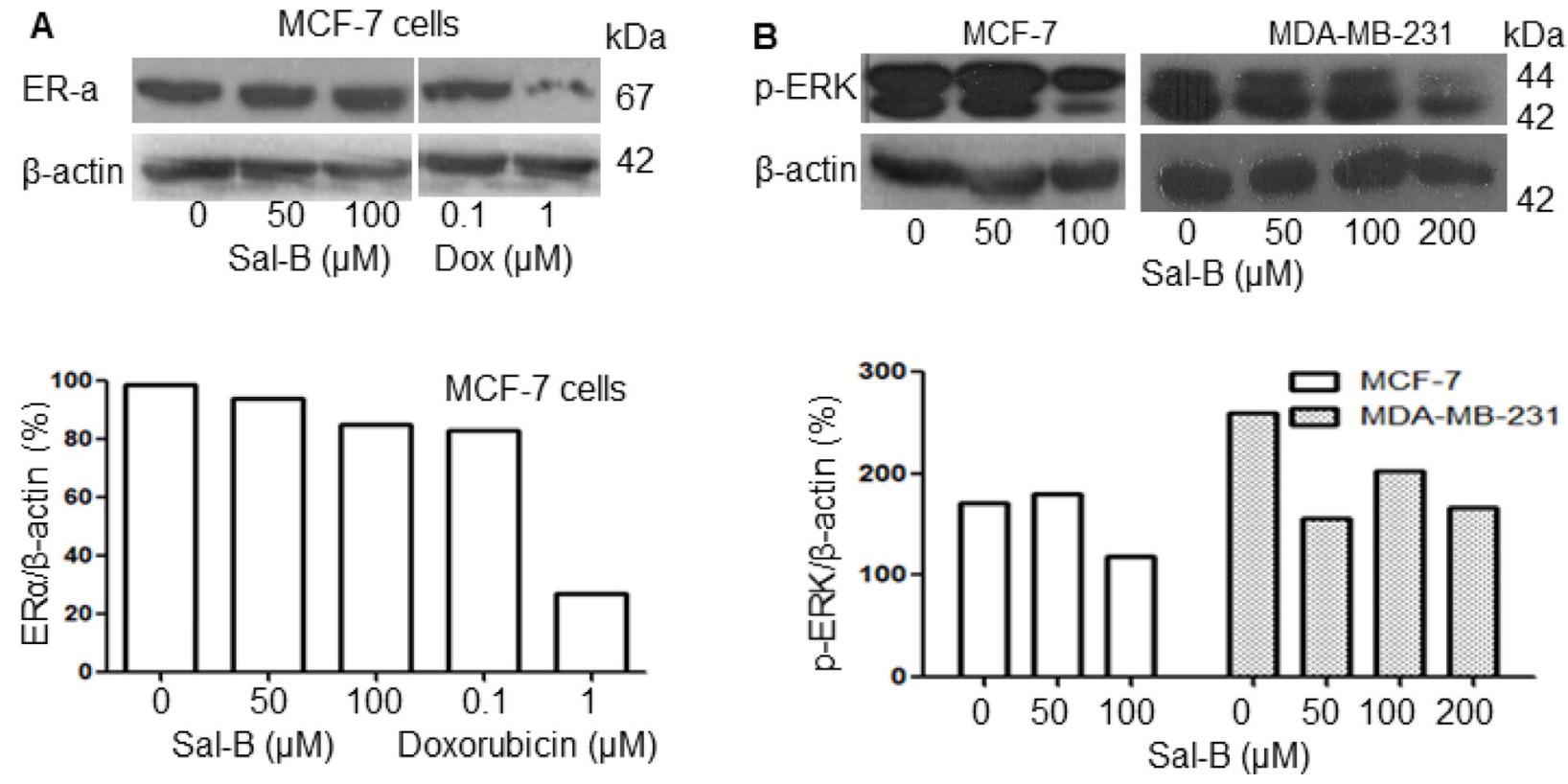

Figure 6: Effects of Sal-B on the ER- $\alpha$ and p-ERK expression in breast cancer cells with Western blot analysis. (A) shows the ER- $\alpha$ expression in MCF-7 cells treated with Sal-B and doxorubicin (upper panel) and (B) shows the expression of p-ERK in MCF-7 and MDA-MB-231 cells following exposure to different concentrations of Sal-B for 24 hours (upper panel). The amount of protein was normalized by that of the internal control $\beta$-actin (lower panel). 
powder with $70 \%$ ethanol in Soxhlet extractor. The extract was then passed through a D101 Macroporous resin and the magnesium salt of Sal-B was eluted with a six-fold column volume of $20 \sim 40 \%$ ethanol solutions. The Sal-B magnesium salt-rich fraction in $40 \%$ ethanol was concentrated and converted into free Sal-B by adjusting to $\mathrm{pH} 3-4$ with hydrochloric acid. The free Sal-B was dried and dissolved in water and purified with a polyamide chromatographic column. The highly purified Sal-B (>95\%) was analyzed with high-pressure liquid chromatography. Before use, the purified Sal-B was dissolved in molecular grade water.

Doxorubicin was extracted from commercially available Adriamycin solution (Bedford Lab, Bedford, $\mathrm{OH})$. The monoclonal or polyclonal antibodies against ceramides, survivin, Bcl-xL, caspase-3, caspase-8, cyclin A, cyclin B1, and PCNA were purchased from Sigma (St. Louis, MO). The anti-ceramide monoclonal antibody (clone: MID 15B4) recognizes free and bound ceramides and its reactivity is species independent. The antibodies against $\beta$-actin and $p$-ERK were obtained from Santa Cruz (Santa Cruz, CA). The antibodies against GCS and GM3 synthase were obtained from NOVUS (Cambridge, UK) and anti-ER- $\alpha$ antibody was from Dako (Carpinteria, CA).

\section{Cells lines and culture}

MCF-7 and MDA-MB-231 human breast cancer cell lines stably transfected with firefly luciferase gene were purchased from Caliper Life Sciences (Hanover, MD). MCF-7 cells were cultured in DMEM medium (Invitrogen, Carlsbad, CA) and MDA-MB-231 cells were grown in DMEM/F-12 (1:1) medium (Invitrogen). Both media were supplemented with 10\% fetal bovine serum (Invitrogen) and antibiotic-antimycotic mixture $(100 \mathrm{IU} / \mathrm{ml}$ penicillin and 100 $\mu \mathrm{g} / \mathrm{ml}$ streptomycin; Cellgro). The cells were maintained at $37^{\circ} \mathrm{C}$ in $5 \% \mathrm{CO}_{2}$. All experiments were performed when the cells were in the logarithmic phase of growth.

\section{Luciferase-base bioluminescent optical analysis}

The culture cells $(10,000$ per well) were seeded in flat-bottomed 96-well plate in the proper medium with $10 \%$ fetal bovine serum and allowed to grow overnight. The old medium was then replaced with fresh medium containing different concentrations of Sal-B $(50,100$, 150 , and $200 \mu \mathrm{M})$ or doxorubicin $(0.1,0.2,0.5$, and $1 \mu \mathrm{M})$. The cells were further cultured for 24 hours and D-luciferin was added to each well and mixed gently (final concentration of $150 \mu / \mathrm{ml})$. The signal was measured with the Xenogen IVIS 200 imaging system (Caliper Life Sciences, Hopkinton, MA, USA). The system is equipped with a highly sensitive, cooled charge-coupled device (CCD) camera and a light-tight specimen box. Imaging and quantification of signals is controlled by the acquisition and analysis software Living Image 3.0. The bioluminescent signal from the cells in each well was expressed as total flux (photons per second $[\mathrm{p} / \mathrm{s}]$ ). At least five replicates were performed in each experiment, and each experiment was repeated at least three times. The representative data were presented.

\section{Colony formation assay}

The colony formation assay was performed as described previously [45]. Briefly, Cells were seeded at a density of 300 cells per well in the 6-well plates, cultured overnight and then treated with Sal-B at different concentrations (1, $10,20,50$, and $100 \mu \mathrm{M}$ ) for 24 hours. Following treatment, the old medium containing Sal-B was replaced with fresh drug-free medium and the cells were allowed to grow for 10 days to permit colony formation from viable clonogenic cells. Colonies were stained with $0.1 \%$ trypan blue in $50 \%$ ethanol and were counted manually under microscopy with a grid printed on a transparent plastic sheet to keep track of colonies counted. The colonies containing more than 50 cells

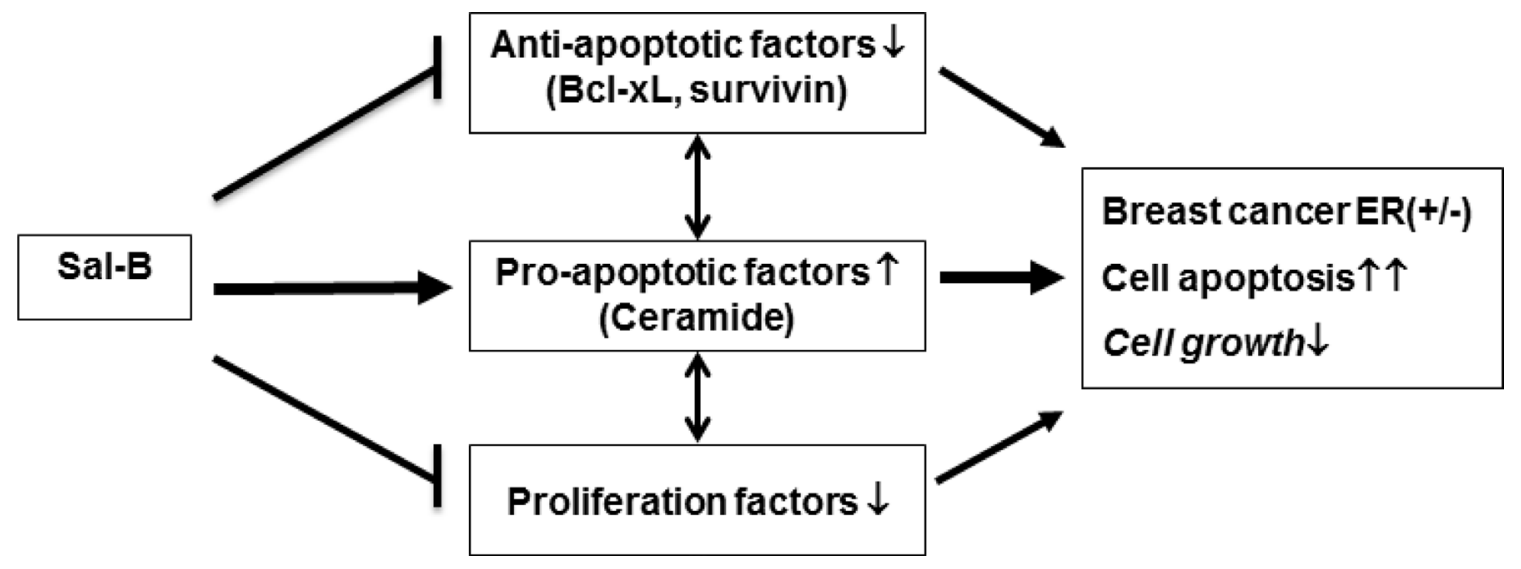

Figure 7: Proposed mechanisms of the antitumor effects of Sal-B on breast cancer cells. Sal-B depresses cell growth and induces cell apoptosis in triple-negative breast cancer cells via (1) decreasing expression of anti-apoptotic factors (Bcl-XL and survivin); (2) enhancing expression of pro-apoptotic factors (i.e., ceramide); and (3) inhibiting proliferation factors. The antitumor activity of Sal-B suggests that Sal-B is highly promising to be a new therapeutic agent against triple-negative breast cancer. 
were considered to represent a viable clonogenic cell. The experiment was done in triplicate for each treatment.

\section{Flow cytometry}

For cell cycle analysis, the cells from both lines were treated with Sal-B (50 and $100 \mu \mathrm{M})$ or doxorubicin $(0.1$ and $1 \mu \mathrm{M})$ for 24 hours and then fixed in chilled $80 \%$ ethanol. The fixed cells were incubated in a solution containing $100 \mu \mathrm{g} / \mathrm{mL}$ RNase at $37^{\circ} \mathrm{C}$ water bath for 45 minutes. Propidium iodide (final concentration of $50 \mu \mathrm{g} / \mathrm{ml}$ ) was then added to the cells and incubated in a $37^{\circ} \mathrm{C}$ water bath for another 15 minutes. To analyze the ceramide level, the fixed cells were sequentially incubated with anti-ceramide primary antibody (1:100) for 2 hours and PE-labeled secondary antibody (1:200) for 30 minutes. The analysis was carried out with a FACStar flow cytometer (Becton Dickinson, San Jose, CA). Ten thousand cells per sample were analyzed, each sample was done in triplicate and the experiment was repeated three times.

\section{Western blot analysis}

Proteins were extracted from the cells with RIPA lysis buffer (Santa Cruz Biotechnology, Santa Cruz, CA) and the protein concentrations were quantified with BioRad protein quantification kit. Whole-cell proteins were separated on $8 \%$ SDS-polyacrylamide gel, transferred to the polyvinylidene difluoride membrane (Bio-Rad), and then probed with the indicated primary antibodies overnight at $4^{\circ} \mathrm{C}$. Washed blots were then incubated with horseradish peroxidase-conjugated anti-rabbit, anti-mouse, or anti-goat antibody (Santa Cruz Biotechnology), respectively, for one hour at room temperature. Blots were developed and visualized with ECL detection system (Bio-Rad).

\section{Immunohistochemical staining}

Immunohistochemical staining was performed as described previously [45]. Deparaffinized specimens were first labeled with anti-PCNA, Bcl-xL, survivin or ceramide antibody and secondary antibody sequentially. The slides were then stained with streptavidin-horseradish peroxidase and imaged with a microscope equipped with a camera and linked to a computer. For the quantification, ten high-magnification $(40 \times)$ fields were randomly selected from each slide of tumors and the positive cells were counted. The protein expression was expressed as the average number of positive cells per high magnification field.

\section{Human tumor xenografts in athymic nude mice}

The animal protocol was approved by the Howard University Animal Care and Use Committee. Four-weekold female athymic nude mice $(\mathrm{Nu} / \mathrm{Nu})$ were obtained from Harlan Sprague Dawley (Indianapolis, IN). All mice were provided the Harlan Teklad \#2018 Global $18 \%$ protein rodent diet and water ad libitum. Mice were housed in temperature-controlled rooms (74 \pm $2^{\circ} \mathrm{F}$ ) with a 12-hour alternating light-dark cycle. MDAMB-231 cells $\left(3 \times 10^{6} / 50 \mu \mathrm{L} /\right.$ spot $)$ were subcutaneously injected into the both sides of lower back of mice using a 27-gauge needle. On the day 10 after cell implantation, the mice with tumors $(\sim 5 \mathrm{~mm}$ in diameter $)$ were randomly divided into Sal-B treated, doxorubicin treated, and untreated groups (five mice per group), and were administrated Sal-B ( $80 \mathrm{mg} / \mathrm{kg}$, three times per week), doxorubicin (4 mg/kg, every four weeks) and $0.9 \%$ saline ( $50 \mu \mathrm{l}$, three times per week), respectively, by intraperitoneal injection. Mouse weight was measured once a week and tumor size was monitored by manual measurement with a caliper. All mice were sacrificed on day 37.

\section{Terminal deoxynucleotidyl transferase-mediated dUTP nick end labeling (TUNEL) assay}

Apoptotic cell death in tumor xenograft tissue sections was determined by TUNEL assay using the TdT-FragEL DNA Fragmentation Detection Kit (EMD Millipore, Burlington, MA) as described previously [24]. Briefly, sections were digested with proteinase $\mathrm{K}$, and endogenous peroxidase activity was blocked with $3 \%$ hydrogen peroxide in $10 \mathrm{mM}$ Tris ( $\mathrm{pH} \mathrm{8.0)}$ ). The sections were then placed in equilibration buffer and incubated with TdT enzyme in a humid chamber at $37^{\circ} \mathrm{C}$ for $1.5 \mathrm{~h}$. The apoptotic nuclei were stained by $3,3^{\prime}$-diaminobenzidine and observed by microscopy. We manually counted the number of positively stained nuclei and the percentage of positive cells versus the total number of cells was calculated.

\section{Statistical analysis}

Values represent the means \pm SD of a minimum of three replicate tests. Data were analyzed by the Duncan test following the ANOVA procedure when multiple comparisons were made. Differences were considered significant when $P<0.05$.

\section{Author contributions}

$\mathrm{XG}, \mathrm{YZ}$ and WS participated in the design and performed the most of the experiments in vitro and in vivo experiments. ZL carried out the immunohistochemical staining. PW provided the cell lines and he together with YF coordinated bioluminescent optical imaging. XG and XP helped to isolate and purify Sal-B. WS, YZ and GX performed the data statistical analysis. XG, WS and GX drafted the manuscript and all authors read and approved the final manuscript. 


\section{ACKNOWLEDGMENTS}

We thank Ms. Dan Zhang for her excellent technical assistance, and Drs. Liang Shan and Ravinder Singh for editing the manuscript.

\section{CONFLICTS OF INTEREST}

The authors declare no potential conflicts of interest.

\section{GRANT SUPPORT}

This work was supported in part by the funding from NIH 1R15DE02138, P20CA192989 and RCMI G12 MD007597, USAMRMC W81XWH-10-1-0767, and Tianjue Gu Foundation.

\section{REFERENCES}

1. CDC. Cancer among women. In: CDC. 2017. https://www. cdc.gov/cancer/dcpc/data/women.htm. Accessed February 27 th 2018

2. Siegel R, Ma J, Zou Z, Jemal A. Cancer statistics, 2014. CA Cancer J Clin. 2014; 64:9-29.

3. Diana A, Franzese E, Centonze S, Carlino F, Della Corte CM, Ventriglia J, Petrillo A, De Vita F, Alfano R, Ciardiello F, Orditura M. Triple-negative breast cancers: systematic review of the literature on molecular and clinical features with a focus on treatment with innovative drugs. Curr Oncol Rep. 2018; 20:76.

4. Chougule MB, Patel AR, Jackson T, Singh M. Antitumor activity of noscapine in combination with doxorubicin in triple negative breast cancer. PLoS One. 2011; 6:e17733.

5. McKenna MT, Weis JA, Barnes SL, Tyson DR, Miga MI, Quaranta V, Yankeelov TE. A predictive mathematical modeling approach for the study of doxorubicin treatment in triple negative breast cancer. Sci Rep. 2017; 7:5725.

6. Ottewell PD, Lefley DV, Cross SS, Evans CA, Coleman RE, Holen I. Sustained inhibition of tumor growth and prolonged survival following sequential administration of doxorubicin and zoledronic acid in a breast cancer model. Int J Cancer. 2010; 126:522-532.

7. Che J, Huang Y, Xu C, Zhang P. Increased ceramide production sensitizes breast cancer cell response to chemotherapy. Cancer Chemother Pharmacol. 2017; 79:933-941.

8. Ogretmen B. Sphingolipid metabolism in cancer signaling and therapy. Nat Rev Cancer. 2018; 18:33-50.

9. Separovic D, Kelekar A, Nayak AK, Tarca AL, Hanada K, Pierce JS, Bielawski J. Increased ceramide accumulation correlates with downregulation of the autophagy protein ATG-7 in MCF-7 cells sensitized to photodamage. Arch Biochem Biophys. 2010; 494:101-105.
10. Vethakanraj HS, Sesurajan BP, Padmanaban VP, Jayaprakasam M, Murali S, Sekar AK. Anticancer effect of acid ceramidase inhibitor ceranib-2 in human breast cancer cell lines MCF-7, MDA MB-231 by the activation of SAPK/JNK, p38 MAPK apoptotic pathways, inhibition of the Akt pathway, downregulation of ERalpha. Anticancer Drugs. 2018; 29:50-60.

11. Hakomori S. Tumor malignancy defined by aberrant glycosylation and sphingo(glyco)lipid metabolism. Cancer Res. 1996; 56:5309-5318.

12. Wegner MS, Gruber L, Mattjus P, Geisslinger G, Grosch $\mathrm{S}$. The UDP-glucose ceramide glycosyltransferase (UGCG) and the link to multidrug resistance protein 1 (MDR1). BMC Cancer. 2018; 18:153.

13. Lee WK, Kolesnick RN. Sphingolipid abnormalities in cancer multidrug resistance: chicken or egg? Cell Signal. 2017; 38:134-45.

14. Reynolds CP, Maurer BJ, Kolesnick RN. Ceramide synthesis and metabolism as a target for cancer therapy. Cancer Lett. 2004; 206:169-180.

15. Hait NC, Maiti A. The role of sphingosine-1-phosphate and ceramide-1-phosphate in inflammation and cancer. Mediators Inflamm. 2017; 2017:4806541

16. Wu JN. An illustrated Chinese material medica. Oxford University Press. 2005; 706.

17. Wang X, Morris-Natschke SL, Lee KH. New developments in the chemistry and biology of the bioactive constituents of Tanshen. Med Res Rev. 2007; 27:133-148.

18. Huang KC. The pharmacology of Chinese herbs. CRC Publishers. 1992; 2nd ed:388.

19. Hao Y, Xie T, Korotcov A, Zhou Y, Pang X, Shan L, Ji H, Sridhar R, Wang P, Califano J, Gu X. Salvianolic acid B inhibits growth of head and neck squamous cell carcinoma in vitro and in vivo via cyclooxygenase- 2 and apoptotic pathways. Int J Cancer. 2009; 124:2200-2209.

20. Chen RC, Sun GB, Ye JX, Wang J, Zhang MD, Sun XB. Salvianolic acid B attenuates doxorubicin-induced ER stress by inhibiting TRPC 3 and TRPC 6 mediated $\mathrm{Ca}(2+)$ overload in rat cardiomyocytes. Toxicol Lett. 2017; 276:21-30.

21. Zhang JY, Zhang B, Wang M, Wang W, Liao P, Sun GB, Sun XB. Calcium homeostasis and endoplasmic reticulum stress are involved in Salvianolic acid B-offered protection against cardiac toxicity of arsenic trioxide. Oncotarget. 2017; 8:97384-93. https://doi.org/10.18632/oncotarget.22127.

22. Wang ZS, Luo P, Dai SH, Liu ZB, Zheng XR, Chen T. Salvianolic acid B induces apoptosis in human glioma U87 cells through p38-mediated ROS generation. Cell Mol Neurobiol. 2013; 33:921-928.

23. Zhao Y, Hao Y, Ji H, Fang Y, Guo Y, Sha W, Zhou Y, Pang $\mathrm{X}$, Southerland WM, Califano JA, Gu X. Combination effects of salvianolic acid B with low-dose celecoxib on inhibition of head and neck squamous cell carcinoma 
growth in vitro and in vivo. Cancer Prev Res (Phila). 2010; 3:787-796.

24. Li H, Shi L, Wei J, Zhang C, Zhou Z, Wu L, Liu W. Cellular uptake and anticancer activity of salvianolic acid B phospholipid complex loaded nanoparticles in head and neck cancer and precancer cells. Colloids Surf B Biointerfaces. 2016; 147:65-72.

25. Li GG, Guo ZZ, Ma XF, Cao N, Geng SN, Zheng YQ, Meng MJ, Lin HH, Han G, Du GJ. The M2 macrophages induce autophagic vascular disorder and promote mouse sensitivity to urethane-related lung carcinogenesis. Dev Comp Immunol. 2016; 59:89-98.

26. Gu X, Song X, Dong Y, Cai H, Walters E, Zhang R, Pang X, Xie T, Guo Y, Sridhar R, Califano JA. Vitamin E succinate induces ceramide-mediated apoptosis in head and neck squamous cell carcinoma in vitro and in vivo. Clin Cancer Res. 2008; 14:1840-1848.

27. Hudis CA, Gianni L. Triple-negative breast cancer: an unmet medical need. Oncologist. 2011; 16:1-11.

28. Avery TP. Triple-Negative Breast Cancer. Changing Paradigms in the Management of Breast Cancer. Cham: Springer. 2018: 155-66.

29. Tan T, Dent R. Triple-Negative Breast Cancer: Clinical Features. Triple-Negative Breast Cancer. Cham: Springer. 2017: 23-32.

30. Green JA, Slater AJ, Campbell IR, Kelly V. Advanced breast cancer: a randomized study of doxorubicin or mitoxantrone in combination with cyclophosphamide and vincristine. Breast Cancer Res Treat. 1996; 39:155-163.

31. Bennett JM, Muss HB, Doroshow JH, Wolff S, Krementz ET, Cartwright K, Dukart G, Reisman A, Schoch I. A randomized multicenter trial comparing mitoxantrone, cyclophosphamide, and fluorouracil with doxorubicin, cyclophosphamide, and fluorouracil in the therapy of metastatic breast carcinoma. J Clin Oncol. 1988; 6:1611-1620.

32. Henderson IC, Allegra JC, Woodcock T, Wolff S, Bryan S, Cartwright K, Dukart G, Henry D. Randomized clinical trial comparing mitoxantrone with doxorubicin in previously treated patients with metastatic breast cancer. J Clin Oncol. 1989; 7:560-571.

33. Gluz O, Nitz UA, Harbeck N, Ting E, Kates R, Herr A, Lindemann W, Jackisch C, Berdel WE, Kirchner H, Metzner B, Werner F, Schütt G, et al, and West German Study Group. Triple-negative high-risk breast cancer derives particular benefit from dose intensification of adjuvant chemotherapy: results of WSG AM-01 trial. Ann Oncol. 2008; 19:861-870.

34. Yi SY, Ahn JS, Uhm JE, Lim DH, Ji SH, Jun HJ, Kim KH, Chang MH, Park MJ, Cho EY, Choi YL, Park YH, Im YH. Favorable response to doxorubicin combination chemotherapy does not yield good clinical outcome in patients with metastatic breast cancer with triple-negative phenotype. BMC Cancer. 2010; 10:527.

35. Keam B, Im SA, Kim HJ, Oh DY, Kim JH, Lee SH, Chie EK, Han W, Kim DW, Moon WK, Kim TY, Park IA,
Noh DY, et al. Prognostic impact of clinicopathologic parameters in stage II/III breast cancer treated with neoadjuvant docetaxel and doxorubicin chemotherapy: paradoxical features of the triple negative breast cancer. BMC Cancer. 2007; 7:203.

36. Lai L, Chen J, Wang N, Zhu G, Duan X, Ling F. MiRNA$30 \mathrm{e}$ mediated cardioprotection of ACE2 in rats with Doxorubicin-induced heart failure through inhibiting cardiomyocytes autophagy. Life Sci. 2017; 169:69-75.

37. Smith L, Watson MB, O'Kane SL, Drew PJ, Lind MJ, Cawkwell L. The analysis of doxorubicin resistance in human breast cancer cells using antibody microarrays. Mol Cancer Ther. 2006; 5:2115-2120.

38. Dartier J, Lemaitre E, Chourpa I, Goupille C, Servais S, Chevalier S, Maheo K, Dumas JF. ATP-dependent activity and mitochondrial localization of drug efflux pumps in doxorubicin-resistant breast cancer cells. Biochim Biophys Acta. 2017; 1861:1075-1084.

39. Gomez LA, de Las Pozas A, Reiner T, Burnstein K, PerezStable C. Increased expression of cyclin B1 sensitizes prostate cancer cells to apoptosis induced by chemotherapy. Mol Cancer Ther. 2007; 6:1534-1543.

40. Liu YY, Yu JY, Yin D, Patwardhan GA, Gupta V, Hirabayashi Y, Holleran WM, Giuliano AE, Jazwinski SM, Gouaze-Andersson V, Consoli DP, Cabot MC. A role for ceramide in driving cancer cell resistance to doxorubicin. FASEB J. 2008; 22:2541-2551.

41. Delpy E, Hatem SN, Andrieu N, de Vaumas C, Henaff M, Rucker-Martin C, Jaffrezou JP, Laurent G, Levade T, Mercadier JJ. Doxorubicin induces slow ceramide accumulation and late apoptosis in cultured adult rat ventricular myocytes. Cardiovasc Res. 1999; 43:398-407.

42. Uchida $Y$, Itoh M, Taguchi Y, Yamaoka S, Umehara H, Ichikawa S, Hirabayashi Y, Holleran WM, Okazaki T. Ceramide reduction and transcriptional up-regulation of glucosylceramide synthase through doxorubicin-activated Sp1 in drug-resistant HL-60/ADR cells. Cancer Res. 2004; 64:6271-6279.

43. Yang XH, Sladek TL, Liu X, Butler BR, Froelich CJ, Thor AD. Reconstitution of caspase 3 sensitizes MCF-7 breast cancer cells to doxorubicin- and etoposide-induced apoptosis. Cancer Res. 2001; 61:348-354.

44. Jansson S, Bendahl PO, Grabau DA, Falck AK, Ferno M, Aaltonen K, Ryden L. The three receptor tyrosine kinases c-KIT, VEGFR2 and PDGFRalpha, closely spaced at 4q12, show increased protein expression in triple-negative breast cancer. PLoS One. 2014; 9:e102176.

45. Hao Y, Gu X, Zhao Y, Greene S, Sha W, Smoot DT, Califano J, Wu TC, Pang X. Enforced expression of miR101 inhibits prostate cancer cell growth by modulating the COX-2 pathway in vivo. Cancer Prev Res (Phila). 2011; 4:1073-1083. 